Section Architecture and Design

\title{
STREETS IN NABLUS OLD TOWN: REPOSITORIES FOR CULTURAL IDENTITY AND COLLECTIVE MEMORY
}

\author{
Muath Taher ${ }^{1}$ \\ Dr. Jorge Correia ${ }^{1}$ \\ ${ }^{1}$ University of Minho, Portugal
}

\begin{abstract}
Although streets are empty spaces, they have a strong effect on one's perception of the city. They work as a key reference in space and time that influence people's mental map and facilitate their orientation. Not only they may carry footprints of past civilizations, but also they provide a place for public activities, whether cultural or functional.

This paper tries to search for the role of streets and its representation in the old town of Nablus, Palestine. It aims at understanding their role in keeping people's collective memory and in representing cultural identity. To achieve this objective, a field survey was conducted. Together with a critical review of traditional Islamic cities' street network, the paper wishes to better understand the street layout and its current dynamics.

In Nablus old town, streets still trace the memory of the original Roman grid of the city, as well as showing later transformations to accommodate human needs throughout time. Mainly an Arab and Muslim neighborhood for the past centuries, its streets exhibit a hierarchy from public to private that represents not just the roles and functions of collective activity, but also the degrees of accessibility and respect for privacy. As in many other Islamic historical contexts, main streets provide a space for everyday life and collective memory, while secondary ones (or even private lanes) are left for the individual to develop and organize according to his private lifestyle patterns. The result shows that streets are a repository for cultural identity and collective memory, tracing back the city's urban history, and fostering a comprehensive cultural ground for contemporary urban reconstruction and regeneration processes.
\end{abstract}

Keywords: Streets, collective memory, cultural identity, Nablus.

\section{INTRODUCTION}

Streets are an important part of the urban tissue. They work as orientation canals, connecting different parts of the city. Their edges determine building lines and blocks. Moving experience through streets defines the city form on people's mind and gives, as an impression about the city [1].

People's common and shared activates take place in streets and open spaces, varying from leisure, commercial, social, entertaining and many other activities. In this sense, streets can take other dimensions, as representative features to the cultural identity as they are socially constructed in response to people's common culture and needs, recording details of their daily life [2]. Therefore the resulting streets and its architecture have significant meanings to its members. 
Historically, streets are almost a permanent element. Because of their public nature and functional reflection, they witness different epochs and last over time. This permanency provides a sense of memory [3], whose layers get deposited installed, keeping links with past history and generations [4]. The sociologist Murec Halbwachs's believes that memories are socially constructed around the concept of space. Memory needs stability to be conserved and this stability can be provided by spatial imageries (durability of streets). Therefore, a certain group of people in a certain geography receives these imprints, allowing for the discovery of the past in a current state of place [2]. Thus, a place constructed by people and shaped by their common values will conserve their collective memory too [1].

Resulting from functional and cultural facts, streets become accordingly strong elements in the urban fabric, playing an important role for perception placement, shaping mental maps and providing space for people to interact and reflect culture [1]. Understanding streets' meanings and representations is important to comprehend its role in storing cultural identity and collective memory. Moreover, this understanding can inform the urban reconstruction or regeneration projects which may take place in the future.

Historically for Nablus old town, as a typical representative of the Arab-Islamic cities, with a unique street character, several cultural factors were responsible at forming and reshaping the street hierarchy, architecture and function. Realizing street values, while taking into account transformation factors, can assist in unfolding the social role of such built palimpsest.

\section{NABLUS STREET SYSTEM, A HISTORICAL URBAN PRINT AND ECHO}

Nablus history goes back thousands of years ago. Nevertheless, the current location of the old town was established by the Romans in the early beginning of the first millennium and called Neapolis [5]. Still today Nablus streets testify for the strong imprint this historical layer has left.

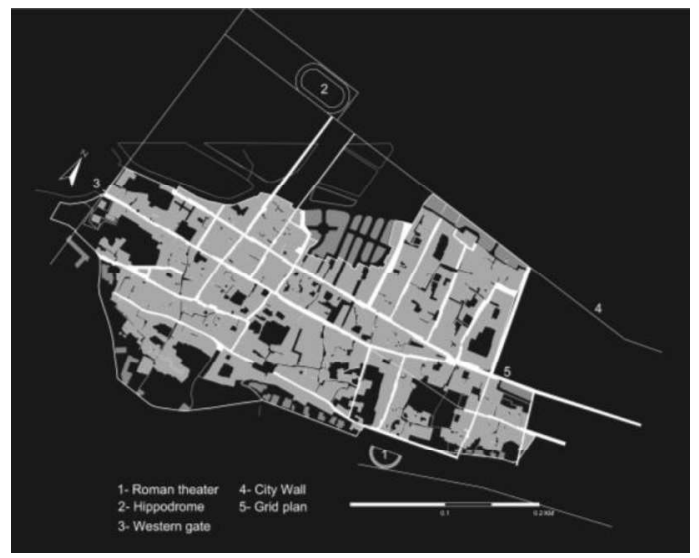

Figure 1: Roman street layout of Flavian Neapolis (Nablus), according to Nablus, Enduring Heritage and Continuing Civilization. 2011. [6]

As the majority of Roman cities, Neapolis' street display followed the grid system. The street layout consisted of a main axis (decumanus maximus) which sectioned the city from east to west. It was crossed by several secondary streets at right angles forming a 
chess pattern network [5]. (Figure 1) Centuries later, when Neapolis became the Arab city of Nablus and due to cultural changements, gradual transformations started to occur in its urban fabric. The street layout was gradually evolving from a grid system to a different conception of street hierarchy. A heavily geometrical street network was giving place to a much more organic one, relying on alternative ways of understanding degrees of privacy.

Besides this fact, Nablus street layout is still quite indexed to the Roman period, when it was one of the biggest Roman cities in the region. Classical linearity can still be read in a street network owing its matrix to the Roman grid plan. The two main east-west streets of the old town, deriving from the Roman scheme, today host the commercial center - the souk. The secondary street network is still responsible for the urban morphological canal organization that commands today's old town of Nablus.

However, the Roman matrix was subjected to both economic and functional needs, or cultural and social factors, that have strongly affected its continuous transformation [7]. Therefore and during time, the city urban fabric flexibly responded to such agents while keeping its accumulated layered historical identity.

\section{STREET PHYSICAL CHARACTERISTICS}

The architectural elements, the function and the space hierarchy of a street all work together to respond to socio-cultural criteria. As a translation of the cultural concept that they serve, streets are given a unique image, ultimately acting for a certain city identity. Characters such as hierarchy, function, coverage or openings, among others, form a sort of language that inform the pedestrian about levels of privacy in the street, and the nature of the neighborhood it crosses.

\section{Hierarchy and function}

As seen before, centuries of Muslim cultural domination have endured a continuous process of adaptation of the classical urban heritage as a response to cultural and social requirements. Today, Nablus old town is composed by six quarters (Yasmina, Gharb, Qaryun, Aqaba, Hableh, Qaysariyya) connected by the inherited street network, yet adapting it to a public-to-private gradation. Main transformations have occurred inside this quarter structure, according to space hierarchy. Streets continue to trace the Roman grid but adjust levels of privacy.

Spaces hierarchy in the city vary from openly public in the commercial area to exclusively private in residential areas. Between them lies a 'buffer' zone that can be considered as a semi-private or semi-public. Character, function, width and level of accessibility change in order to differentiate these areas. Generally speaking, it might be possible to observe three levels of street hierarchy and reflects on the street typology: public streets, semi-public/semi-private streets, and private lanes. (Figure 2)

Main public streets provide a place for economic, social, and cultural activities. Functions of a commercial street are trading and negotiating displayed goods, as well as sitting and entertaining of clients by shop-owners. Buildings on these streets are multistored. Often residential units are placed on the first floor with indirect entrances from a side entrance or through a set of stairs. These major canals connect important city elements such as hammam (public baths), souk (market) or main mosque. 
Drinking fountains - sabil - can also be found in public streets. They are usually architectural elements donated by rich individuals or families in order to provide drinking water for people passing by, whether local or foreigners. This habit of offering people water is a direct reflection of Islamic culture and yet antother sign of how religion is embebedded in the urban character of the city.



Figure 2 : Nablus streets hierarchy (based on field survey)

On the contrary, the nature of the residential street - cul-de-sacs - is different. Mainly they are private streets within the residential quarters. Their width is smaller than the public street, facilitating the accessibility for the neighborhood residents. The private street function within a quarter is played by a hosh most of the times. These lanes work as filter corridors. From main streets to cul-de-sacs leading to each house, Islamic urban culture is significantly more related to social aspects of private life than to geometrical questions of regularity. Hosh in Nablus show a tendency to conduct the pedestrian towards less public and more private areas of circulation. On the one hand it grants accessibility for residents and, on the other, it restricts mobility by keeping strangers and outsiders out and ensuring safety and privacy for its residents. Residential streets act as devices serving the social order in its desire for privacy and exclusion, serving as platforms for social activities among neighbors and providing safe sheltered areas (playgrounds) for children to play.

In fact, the spatial configurations inside residential quarters, as well as house plans, have evolved to consider privacy and neighbors rights as the main urban criteria. Houses were organised around a semi-private alley called hosh. Traditionally shared by houses of the same family, a hosh acquired the family name and was lived by/for family members.

Between the previous two levels, a network of secondary streets crosses them, linking different parts of the old town. They present another level of hierarchy that balances between the semi-public and semi-private sphere. Going towards the residential and private districts, these streets are still characterized by commercial activities but time has twisted them slightly the classical Roman grid. Narrower and more organic, most of the buildings on these streets are multi-stored, mixing functions and gradually conducting the pedestrian to the inner core of the different quarters. 


\section{Architectural devices: coverage and openings}

The street visual character or level of light and shade can tell much about its character in a traditional Islamic city and for Nablus that couldn't be more accurate where many streets are covered. Although the main purpose was to protect people from hot sun or heavy rain, for Nablus as for many other traditional Islamic cities, the coverage with its distribution of shade and light also worked, and still does, as a cultural language that helps identifying the nature of the street, its functionality and degree of privacy.

Nablus' souk (the main commercial street) is covered by a high vaulted roof with punctual skylights. It provides the internal space with good lighting and ventilation, and creates a suitable protected space for the different public activates such as trade and entertainment, as a place for people to speak, share and negotiate. (Figure 3) This coverage composition reflects the public character of the space.

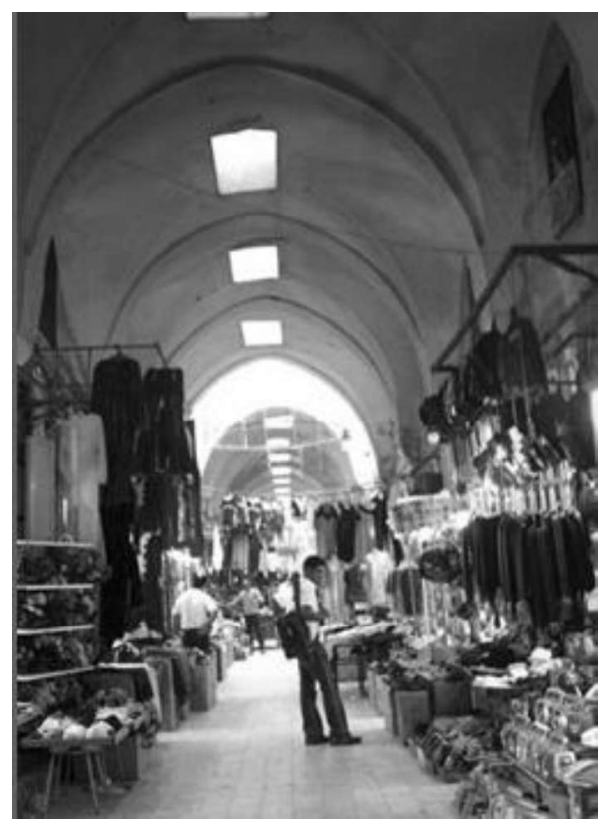

Figure 3: View of Nablus' souk street

As for private lane, leading to residential units, they have a different coverage nature. Its roofing isn't high and doesn't provide light as in the public one. This type of coverage enriches visually the streetscape and the walking experience, creating an atmosphere that doesn't encourage outsiders to enter. (Figure 4) In this quiet lanes, away from hustle and bustle of the commercial one, indivisual right related to the use of the public space get a reverse aerial projection, creating a right of usage to the upper floor and the construction of superior passages over streets - kantara. It consist of a hanging room over the street between building on the both sides of the street. Besides climate advantages, it also provides a structural support for both façades. Visually it gives the sense of enclosure, narrowing visual perspectives. 


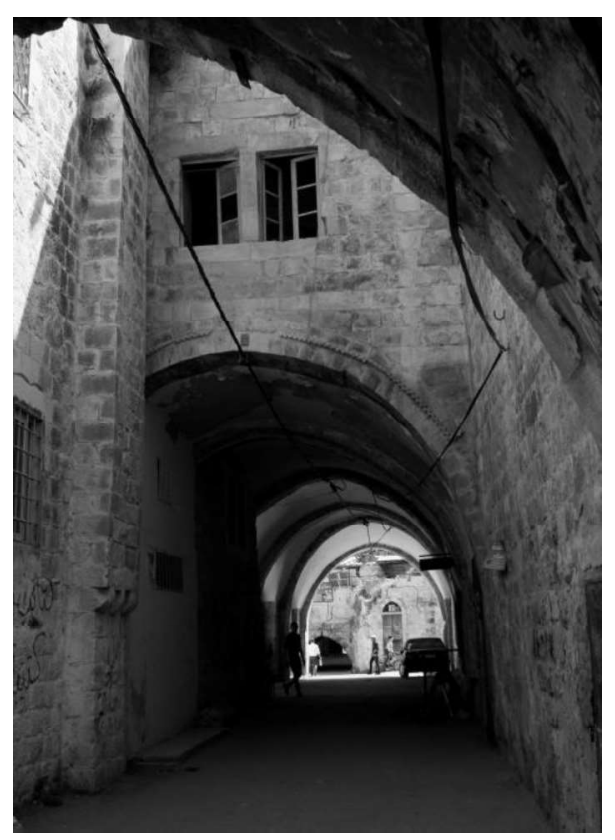

Figure 4: Example of hosh in Nablus's old town

Other architectural devices can be found in street façades. Residential streets did not usually have windows looking into the public space. (Figure 5) When it happened, they are usually opened in a higher position, treated with a special architectural elements to keep the internal privacy. Mashrabia, which is an architectural treatment for windows that allows people to see without being seen are frequently in the upper floors. Made of wood, the mashrabia system is projected out of the window from the building's façade vertical plan. It was also used to hang jars for cooling water, and served as a device to reduce the sun exposition.

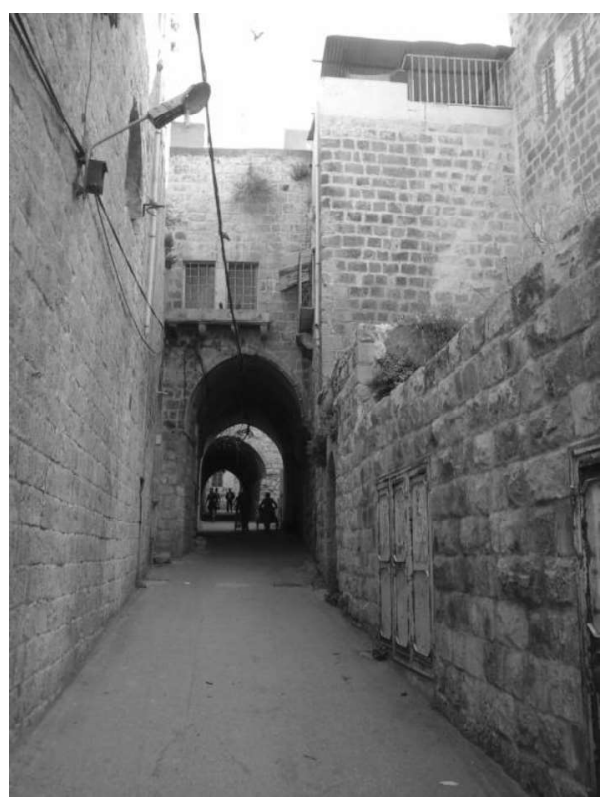

Figure 5: Example of a residential lane 
In an almost blind and quite neutral streetscape scenario, gates and windows are the only elements in a street that could suggest an owners' status. Elaborated arches or ornamented framing work, as well as carved doorways, differentiate a modest household from an urban palace. Whereas the public space belongs to everyone, stepping beyong a house gate means discovering a new world only accessible to residents or guests. Built for pedestrian movement, traditional Islamic cities show a gradation from public to private, from halal - what is allowed or profane - to haram what is fordidden or sacred [8]. These cultural dimensions work as filters at different levels of the urban structure or the building composition.

\section{CONCLUSION}

Summing up, the streets of Nablus' old town carry quite a very strong cultural representation and meaning. People's cultural identity is embodied in its function, organization and architecture elements. Therefore, streets transmit an information that communicates the place's level of privacy and accessibility.

Nablus old town urban fabric has been the result of many historical metamorphoses. Yet, the long-going period of Islamic predominance has lended the city with comparable aspects of the so-called traditional Islamic city. Therefore, within the process of building and urban development, the roots of the structure and the unity prevalent in the vast Islamic world are the product of the Fiqh (Islamic jurisprudence): the mechanism interpreting and applying the value system of the Shari'a (Islamic divine law which derives from the holy Qur'an and the Sunnah) [9]. Hence all the cities inhabited predominantly by Muslims share an Islamic identity which is directly due to the application of Shari'a values in the process of city building. Both the vocabulary and design language and the Fiqh mechanism tended to perpetuate and sustain urban forms and the organisational/planning systems.

In this sense, streets are repositories of experience and tradition, saying something about the cultural identity of the peoples who have created and transformed them. This conclusion, which highlights streets' representation and their role in preserving people cultural identity and collective memory, can inspire the urban regeneration and reconstruction projects, providing a frame on how to deal with streets as an integral part of future projects and not merely as void spaces betwwen divoreced architectural interventions of monuments. Perverting such an established and matured system of urban cohesion is excluding the participation of the public space into a desirable table of reflexion upon urban regeneration for old towns such as Nablus.

\section{REFERENCES}

[1] Lynch, Kevin. The image of the city. MIT press, 1960.

[2] Halbwachs, Maurice, and Lewis A. Coser. On collective memory. University of Chicago Press, 1992.

[3] Hebbert, Michael. "The street as locus of collective memory". Environment and Planning D, 23.4 (2005): 581. 
[4] Meusburger, Peter, Michael Heffernan, and Edgar Wunder, eds. Cultural memories: the geographical point of view. Vol. 4. Springer Science \& Business Media, 2011

[5] Al Fani, Ibrahem. Nablus in Roman and Greek civilizations. Nablus, 1999 [أنغي،

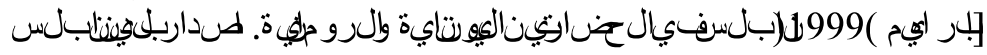

[6] Nablus, Enduring Heritage and Continuing Civilization. The revitalization Plan of the Old City. Coordinated by Shadia Tuqan and Ali Abdul Hamid. Jerusalem: Welfare Association, 2011.

[7] Jaber, Sylvia. Urban streets: towards sustainable mobility in Arabic cities. Master thesis. Stuttgart University, 2013.

[8] Petruccioli, Attilio. Dar al-Islam. Bruxelles: Pierre Mardaga, 1990.

[9] Hakim, Besim S. Arabic-Islamic Cities: Building and Planning Principles. London: KPI, 1986. 